\title{
Vascular Anomalies of the Head and Neck Region
}

\author{
S. C. Nair $^{1,2}$
}

Published online: 5 January 2018

(c) The Association of Oral and Maxillofacial Surgeons of India 2018

\begin{abstract}
Vascular anomalies of the head and neck region are a complex group of lesions that challenge the head and neck physicians. From the very understanding of the difference between its two distinct forms, hemangiomas and vascular malformations to its management remain confusing. The review of this anomaly attempts at comprehensively understanding the disease. Vascular anomalies are easily diagnosed by their clinical presentation, but choice of imaging and management for this spectrum of lesions is varied. The author attempts to categorize the required imaging for the lesion with suggestions on the management of both hemangiomas and vascular malformations. The available treatment options are discussed, and a comprehensive algorithm for management is suggested. Further research in developing drugs that could restrict the growth of these lesions would be the future of the management of vascular lesions.
\end{abstract}

Keywords Vascular anomalies $\cdot$ Hemangiomas $\cdot$ Vascular malformations

Vascular anomalies (VA) by the very terminology describe a broad spectrum of pathologies involving the vascular structures of the human body. Since the biological differentiation in its classification provided by Mulliken and Glowacki, some clarity has crept into the understanding of the disease. The complexity in diagnosing and therefore

\section{S. C. Nair}

snmaxfax@gmail.com

1 Maxillofacial Surgery Department, Bangalore Institute of Dental Sciences, Bangalore, India

2 Maxillofacial Surgery Department, B M Jain Hospital, Bangalore, India managing the pathology has been largely due to its varied spectrum of presentation. Management for VA varies from medical to minimally interventional and finally radical modalities. This article reviews the history, pathogenesis, classifications and available interventional measures in the literature and our own philosophy of management of vascular anomalies.

\section{Historical Review and Nomenclature}

Wardrop, a surgeon from London, first recognized in 1818 that vascular malformations were different from hemangioma [1]. This, however, did not help develop a philosophy of treatment. The first public demonstration of ether anesthesia by William Green Morton in 1846 was for surgical removal of a venous vascular malformation [2].

For centuries, laymen and physicians called cutaneous vascular nevi by familiar words for food. The use of such terms as "cherry", "port-wine stain" and "strawberry" for vascular lesions can be traced back to this false doctrine of maternal impressions [3]. With the advent of histopathology in the middle of the nineteenth century, these anomalies became known as angiomas. Over the next 100 years, clinical and histological terms became hopelessly jumbled, impeding the development of this field.

\section{Classifications}

Rudolf Ludwig Karl Virchow (1863), the father of cellular pathology, deserves credit as the first to categorize vascular anomalies by microscopic channel architecture [4]. He called them angioma simplex, angioma cavernosum or angioma racemosum. Since then, many classifications have been proposed (Table 1). 
Table 1 Various classifications of vascular anomalies

\begin{tabular}{lll}
\hline Year & Author & Basis of classification \\
\hline 1863 & Virchow RLK & Microscopic channel architecture \\
1877 & Wegener & Histomorphic subclassification of Virchow's classification \\
1973 & Degni and coworkers & Site of origin of the defect \\
1974 & Malan & Embryologic site of origin of the defect \\
1982 & Mulliken JB and Glowacki J & Endothelial characters \\
1983 & Burrows and colleagues & Angiographic flow patterns \\
1988 & International Society for the Study of Vascular Anomalies & Anatomopathologic classification of vascular defects (Hamburg \\
& (ISSVA), Hamburg & classification) \\
1989 & Belov & Etiologic and pathophysiologic classification system \\
1992 & ISSVA, Colorado & Cellular features, vascular flow characteristics and clinical \\
1993 & Jackson and associates & behavior \\
1996 & ISSVA, Rome & Flow rate \\
2011 & S C Nair & Modified ISSVA classification \\
2014 & ISSVA, Melbourne & Anatomical presentation \\
\hline
\end{tabular}

International Society for the Study of Vascular Anomalies (ISSVA) has proposed its first classification in 1988 in Hamburg, which is known as Hamburg classification. And it has been reviewed and modified several times since then, in 1992 in Colorado, in 1996 in Rome and most recently in 2014 in Melbourne [5] (Table 2).

The author introduced a more practical classification to aid in the decision making with respect to diagnostic imaging and the surgical planning as follows [1] (Table 3):

The malformations were categorized into five types depending on their anatomy and depth of location in the head and neck region. In type I superficial lesions requiring excision of skin or mucosa, local or regional flaps have been used in defect reconstruction. Type II submucosal lesions require complete excision after elevation of skin flaps. Type III lymphovenous malformations or venous malformations involving glands of the head and neck are excised along with the affected gland. Type IV intraosseous lesions require excision with involved bone and reconstruction when required. Type $\mathrm{V}$ lesions involving deep visceral spaces, such as the parapharyngeal or infratemporal fossa, require skeletal access osteotomy for complete exposure and total excision. The above classification helped in determining the surgical approach and reconstruction necessary for the type of vascular lesion.

Hemangiomas are subclassified into focal and segmental disease [6]. Focal hemangiomas are localized, unilocular lesions which adhere to the phases of growth and involution. Multifocal hemangiomatosis also exists, and infants with more than five lesions should undergo workup to rule out visceral involvement. Segmental hemangiomas are more diffuse plaque like and can lead to untoward functional and aesthetic outcomes. The limb and face are common locations for the disease.

\section{Incidence}

Overall, infantile hemangiomas have an incidence of $3-10 \%$ in the literature, but more evidenced study confirmed that it is likely 4-5\% [7]. A multicentric prospective study with an aim to identify demographics of infantile hemangiomas concluded female gender, prematurity, multiple gestations, Caucasian ethnicity, low birth weight and advanced maternal age are the associated risk factors [8].

Among vascular lesions, venous malformations are the common along with lymphatic ones having incidence of 1:5000-10,000, and surprisingly $40 \%$ of them usually occur in head and neck regions [9].

\section{Diagnosis}

Clinical diagnosis of hemangiomas generally arises from making a thorough physical examination which considers the shape, consistency and character delineation and possible invasive lesion, with subsequent deterioration of vital functions. In most cases no further investigation is needed, but achieving the differential diagnosis of hemangiomas is imperative to rule out other diseases, which are potentially more serious.

Similarly, venous malformations occurring in superficial areas are usually easy to diagnose by clinical examination. However, for those lesions that are deep in the face and neck, it is sometimes difficult to make a correct diagnosis 


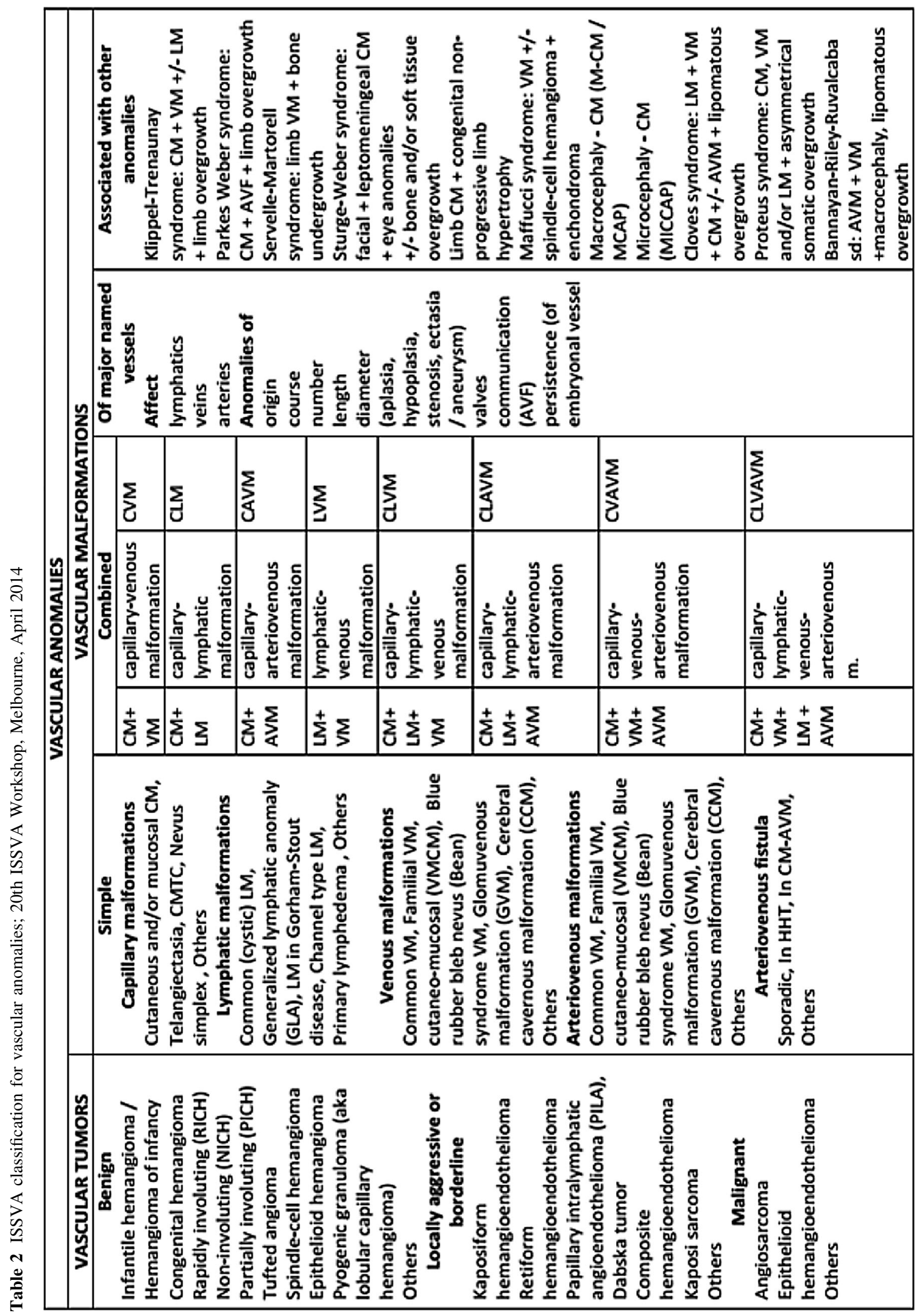


Table 3 Categorization of vascular malformation based on anatomical presentation [1]

\begin{tabular}{ll}
\hline Type I & Mucosal/cutaneous \\
Type II & Submucosal/subcutaneous \\
Type III & Glandular \\
Type IV & Intraosseous \\
Type V & Deep visceral \\
\hline
\end{tabular}

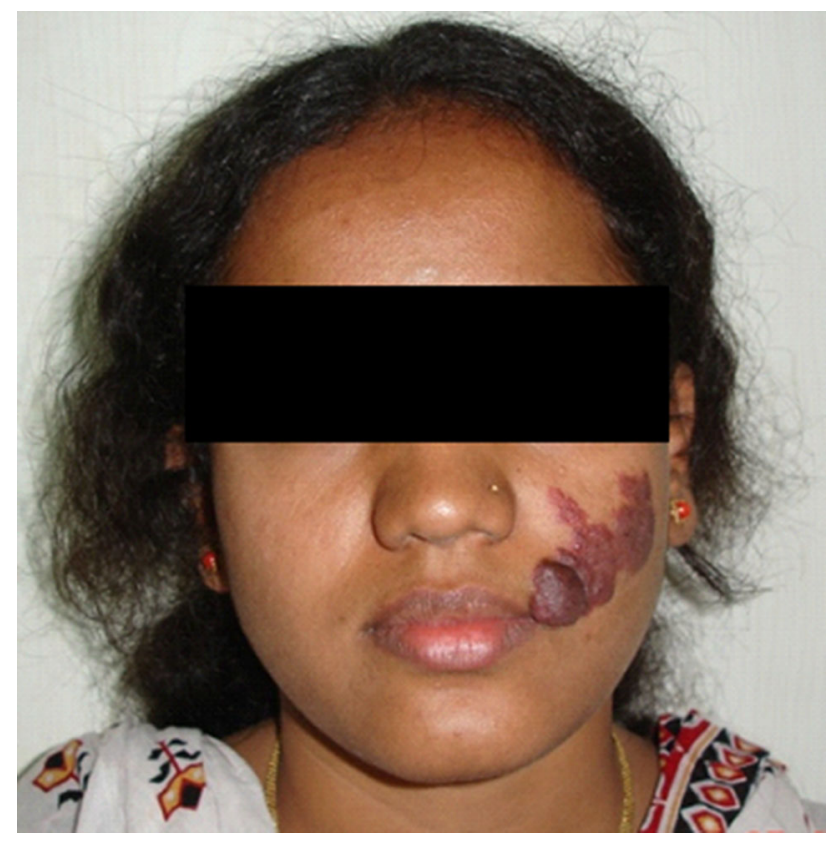

Fig. 1 Clinical presentation of patient having hemangiomatous lesion of face

through clinical examination alone. Imaging studies using ultrasound (US), CT, MRI (MR hemography) are the best diagnostic scans [10].

There are clear differentiating features between hemangiomas (Fig. 1) and vascular malformation (Fig. 2) in their clinical presentation and behavior (Table 4).

The widespread introduction of modernized diagnostic imaging techniques like color Doppler ultrasound (CDUS), MRI, CECT scan, digital subtraction angiography (DSA) (catheterizing the entire vertebral or vascular tree) and MR venography for low-flow lesions has been aiding the surgeon to manage these lesions (Table 5).

In few cases, it is not unusual to see the involvement of parenchyma that provides a valid reason to opt for additional imaging diagnostic modality such as MRI or CT (with or without contrast usage). Sometimes, Doppler USG may be useful in hemangiomas extending to other layers of skin, as a part of changes as in cysts or lymph node changes.

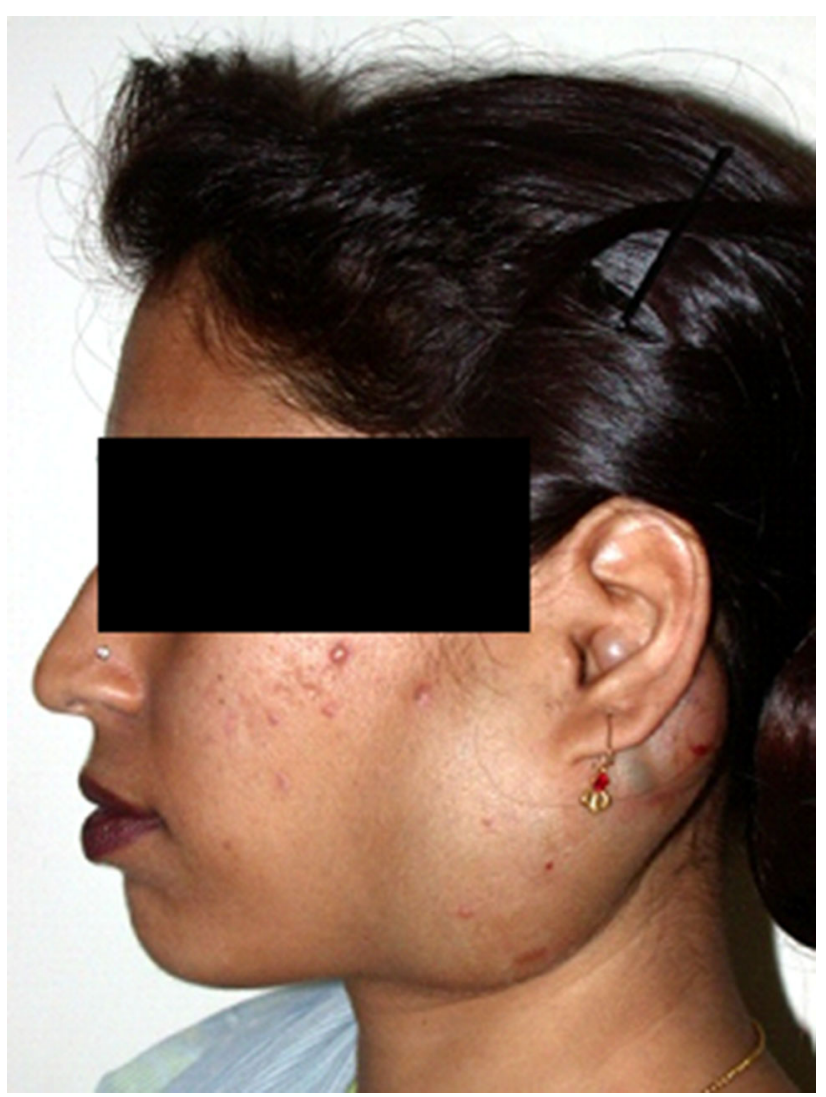

Fig. 2 Clinical presentation of patient having vascular malformation of face

In T2 weighted images (Fig. 3), venous malformations can appear as "venous lakes". MRI sectional images can avoid signal overlap and thereby demonstrate the relationship between the lesion and the deep structure. MRI is therefore superior to CT (Fig. 4) in demonstrating the relationship between the extent of the lesion and normal tissue.

\section{Histopathologic Features [13] (Table 6)}

In distinction to hemangiomas, vascular malformations result from abnormal vascular or lymphatic morphogenesis, not due to abnormal endothelial proliferation. Despite some similarities in appearance between vascular malformations and hemangiomas, the histopathologic features are quite different.

\section{Management of Vascular Anomalies}

Several algorithms for management of vascular lesions have been proposed till date (Fig. 5). 
Table 4 Features of vascular lesions [11]

\begin{tabular}{ll}
\hline Hemangioma & Vascular malformation \\
\hline $\begin{array}{l}\text { Present at birth, most diagnosed by 1 year old } \\
\text { Rapid growth until age 6-8 months, then slows and } \\
\text { involutes by 5-9 years }\end{array}$ & $\begin{array}{l}\text { Present at birth but often not diagnosed until second decade } \\
\text { Slow growth throughout life with increase in response to infection, trauma or hormonal } \\
\text { fluctuation; does not involute } \\
\text { turnover }\end{array}$ \\
$\begin{array}{ll}\text { Osseous involvement rare } \\
\text { Female-to-male ratio 5:1 }\end{array}$ & $\begin{array}{l}\text { Osseous involvement 35\% } \\
\text { Usually low flow }\end{array}$ \\
$\begin{array}{l}\text { Female-to-male ratio 2:1 } \\
\text { Frequently does not need treatment }\end{array}$ & $\begin{array}{l}\text { May be low flow (capillary, venous, lymphatic) or high flow (arterial or arteriovenous) } \\
\text { Often requires treatment }\end{array}$ \\
\hline
\end{tabular}

Table 5 Key imaging features of most common vascular lesions of head and neck [12, 14]

\begin{tabular}{|c|c|c|}
\hline & US with CDUS & MRI \\
\hline $\mathrm{IH}$ & $\begin{array}{l}\text { Hyperechoic or hypoechoic } \\
\text { Hypervascular on CDUS }\end{array}$ & $\begin{array}{l}\text { Iso to intermediate signal on } \mathrm{T} 1 \mathrm{~W} \text {, bright signal on } \mathrm{T} 2 \mathrm{~W} \text {, high- } \\
\text { intensity flow enhancement on gradient echo, internal flow voids } \\
\text { vigorous enhancement after contrast administration }\end{array}$ \\
\hline $\mathrm{RICH}$ & $\begin{array}{l}\text { Central, non-enhancing, hypodense, hypoechoic, more robust } \\
\text { feeding vessels with large diameter than IH }\end{array}$ & $\mathrm{T} 2 \mathrm{~W}$ hyperintense component is quite prominent \\
\hline $\mathrm{NICH}$ & Almost similar to $\mathrm{IH}$ & Almost similar to IH \\
\hline VMs & $\begin{array}{l}\text { Solid echogenic mass with phleboliths, often multispatial and } \\
\text { compressible. Low flow or monophasic or no flow on CDUS }\end{array}$ & $\begin{array}{l}\text { T1W heterogenous intermediate signal, no flow voids, } \mathrm{T} 2 \text { fast spin } \\
\text { echo fat saturated or short } \mathrm{T} 1 \text { inversion recovery high signal } \\
\text { intensity, } \mathrm{T} 1 \mathrm{~W} \text { spin echo postgadolinium enhancement }\end{array}$ \\
\hline LM & $\begin{array}{l}\text { Variable multicystic, multispatial masses, with or without fluid or } \\
\text { debris levels. No flow pattern on CDUS }\end{array}$ & $\begin{array}{l}\text { T1W low to intermediate signal intensity, T2W high signal } \\
\text { intensity, T1W postgadolinium, no enhancement except within } \\
\text { septa }\end{array}$ \\
\hline AVM & $\begin{array}{l}\text { Clusters of vessels with no intervening well-defined mass. High } \\
\text { flow (arterial flow) on CDUS. Arterial and venous signals from } \\
\text { vessels in the lesions with arterializations of venous structure. }\end{array}$ & $\begin{array}{l}\mathrm{T} 1 \mathrm{~W} \text { and } \mathrm{T} 2 \mathrm{~W} \text { sequences show serpiginous signal voids without a } \\
\text { focal mass }\end{array}$ \\
\hline
\end{tabular}

US ultrasound, CDUS color Doppler ultrasound, MRI magnetic resonance imaging, $T 1 W$ T1 weighted, T2W T2 weighted, IH infantile hemangioma, $R I C H$ rapidly involuting congenital hemangioma, $N I C H$ non-involuting congenital hemangioma, $V M$ venous malformation, $L M$ lymphatic malformation, AVMs arteriovenous malformations

Table 6 Salient histopathologic findings of vasoformative tumors (hemangioma and vascular malformations) [13]

\begin{tabular}{ll}
\hline Hemangiomas (proliferative phase) & Endothelial cell hyperplasia forming syncytial masses \\
& Thickened (multilaminated) endothelial basement membrane \\
& Ready incorporation of tritiated thymidine in endothelial cells \\
& Presence of large number of mast cells \\
& Less mitotic activity \\
& Little or no uptake of tritiated thymidine in endothelial cells \\
& Foci of fibrofatty infiltration \\
& Normal mast cell counts \\
& No endothelial cell proliferation \\
& Contains large vascular channels lined by endothelium \\
& Unilamellar basement membrane \\
& Does not incorporate tritiated thymidine in endothelial cells \\
Vascular malformations & Normal mast cell counts
\end{tabular}


Table 7 Sclerosing agents

\begin{tabular}{|c|c|c|c|}
\hline Sclerosing agent & Important facts & Advantages & Disadvantages \\
\hline Bleomycin & $\begin{array}{l}\text { First used by Yura and coworkers in } 1977 \\
\text { [25] }\end{array}$ & $\begin{array}{l}\text { Can absorb systemically at very low } \\
\text { levels, even if administered locally [25] }\end{array}$ & $\begin{array}{l}\text { Development of fatal pulmonary } \\
\text { fibrosis even in low doses [26] } \\
\text { hyperpigmentation }\end{array}$ \\
\hline Pingyangmycin & $\begin{array}{l}\text { Chemical structure similar to Bleomycin } \\
\text { A5, this anticancer drug can be extracted } \\
\text { from gram + ve streptococci }\end{array}$ & $\begin{array}{l}\text { Most effective in treating vascular } \\
\text { malformations of size less than } 5.0 \mathrm{~cm} \\
\text { and for superficial lesions. } \\
\text { Percutaneously, it is very simple and } \\
\text { effective }\end{array}$ & $\begin{array}{l}\text { Allergic reactions, cutaneous or } \\
\text { mucosal necrosis and sensory } \\
\text { nerve or motor nerve injuries }\end{array}$ \\
\hline $\begin{array}{l}5 \% \text { Sodium } \\
\text { morrhuate }\end{array}$ & Earlier, it was successfully used & $\begin{array}{l}\text { May remain in lesion, causing sclerosis } \\
\text { and involution for a longer duration }\end{array}$ & $\begin{array}{l}\text { Irritating and has tendency for the } \\
\text { induction of severe reactions like } \\
\text { tissue necrosis }\end{array}$ \\
\hline Absolute ethanol & $\begin{array}{l}\text { Clinical application over the decades } \\
\text { Used globally, even in complicated and } \\
\text { extensive lesions [27] }\end{array}$ & $\begin{array}{l}\text { Low cost, remarkable results, quick } \\
\text { metabolism and lower recurrence rates } \\
{[28]}\end{array}$ & $\begin{array}{l}\text { Ethanol sclerotherapy is painful } \\
\text { and requires general anesthesia. } \\
\text { Facial palsy and allergy }\end{array}$ \\
\hline $\begin{array}{l}\text { Lauromacrogol } \\
\text { aethoxysklerol } \\
\text { or polidocanol }\end{array}$ & $\begin{array}{l}\text { Most effective sclerosing agents with low } \\
\text { risk of complications and contains } 95 \% \\
\text { hydroxyl polyethoxydodecane with 5\% } \\
\text { ethyl alcohol }\end{array}$ & $\begin{array}{l}\text { Injection technique is simple, safe and } \\
\text { time-saving, painless, rarely allergic } \\
\text { and well tolerated by patients }\end{array}$ & $\begin{array}{l}\text { It may cause necrosis and } \\
\text { ulceration, if solution leaks out } \\
\text { into mucosa or skin }\end{array}$ \\
\hline OK-432 & $\begin{array}{l}\text { OK-432, also called picibanil, is a } \\
\text { biological preparation of lyophilized } \\
\text { powder containing Streptococcus } \\
\text { pyogenes Su strain cells (group A, type } \\
\text { 3) treated with benzylpenicillin } \\
\text { potassium [29] }\end{array}$ & $\begin{array}{l}\text { No perilesional fibrosis [30] } \\
\text { Possibility to perform multiple } \\
\text { subsequent injections with additional } \\
\text { shrinkage response } \\
\text { Low complication rate } \\
\text { Better aesthetics results [30] }\end{array}$ & $\begin{array}{l}\text { The main disadvantage of OK- } 432 \\
\text { is that some lesions require more } \\
\text { than one injection to shrink } \\
\text { satisfactorily. Other } \\
\text { complications include fever, } \\
\text { allergy, erythema and swelling } \\
\text { [31] }\end{array}$ \\
\hline $\begin{array}{l}\text { Detergent } \\
\text { sclerosants } \\
\text { (sodium } \\
\text { tetradecyl, the } \\
\text { most } \\
\text { commonly } \\
\text { used } \\
\text { sclerosant, } \\
\text { ethanolamine } \\
\text { and } \\
\text { polidocanol }\end{array}$ & $\begin{array}{l}\text { Detergents came into use in the } 1930 \text { s } \\
\text { They work by a mechanism known as } \\
\text { protein theft denaturation }\end{array}$ & $\begin{array}{l}\text { Addition of air results in a microfoam } \\
\text { which is felt to be more effective than } \\
\text { the bland solution. A reasonable dose } \\
\text { limit for image-guided Sclerotherapy is } \\
0.5 \mathrm{ml} / \mathrm{kg} \text { or } 30 \text {. }\end{array}$ & $\begin{array}{l}\text { It is painful to inject, but effective } \\
\text { and relatively nontoxic }\end{array}$ \\
\hline
\end{tabular}

The following algorithm was proposed by R. Mattassi, D.A. Loos and M. Vaghi for congenital vascular anomalies (Fig. 6).

These as well as other algorithms given proposed different approaches toward management of hemangioma and vascular malformations.

\section{Management of Hemangiomas}

Hemangiomas due to its biological behavior of proliferation followed by involution can be treated effectively with medications both systemic and intralesional.

As per the literature, around $90 \%$ infantile hemangiomas are small, focal and non-effective to function or aesthetics.
It is encouraged to have a close observation of these lesions during its proliferation [15]. Intervention is only necessary after involution phase, particularly in the presence of excess residual tissue, scarring or telangiectasia. Also, clear indications for intervention are also given when vital systems or structures such as airway or visual pathways are affected, risks of amblyopia, symptomatic or asymptomatic ulcerations, permanent disfigurement threatened by facial lesions or large lesions resulting in cardiac overload [16].

\section{Beta Blockers}

The serendipity of Leaute-Labraze et al. in 2008 resulting in efficacious use of propranolol is remarkable [17]. In their original landmark study, they have done treatment for 
Table 8 Different embolic agents

\begin{tabular}{|c|c|c|c|}
\hline Embolic agent & Important facts & Advantages & Disadvantages and limitations \\
\hline $\begin{array}{l}\text { Polyvinyl alcohol } \\
\text { particles }\end{array}$ & Non-resorbable & $\begin{array}{l}\text { Potential to occlude target } \\
\text { vessel at desired point [34] }\end{array}$ & $\begin{array}{l}\text { High Incidence of inflammatory and foreign body } \\
\text { reactions } \\
\text { Thrombosis and focal angionecrosis of the vessel wal } \\
\text { [36] }\end{array}$ \\
\hline $\begin{array}{l}\text { Trisacryl gelatin } \\
\text { microspheres }\end{array}$ & $\begin{array}{l}\text { Non-resorbable hydrophilic, } \\
\text { biocompatible nontoxic [37] }\end{array}$ & $\begin{array}{l}\text { No tendency for aggregate } \\
\text { formation }\end{array}$ & Fatal sepsis and diffuse necrosis \\
\hline $\begin{array}{l}\text { Polyvinyl Alcohol } \\
\text { Microspheres }\end{array}$ & Resorbable water soluble & $\begin{array}{l}\text { Mild or no inflammatory } \\
\text { response }\end{array}$ & $\begin{array}{l}\text { Higher compressibility of particles and early proxima } \\
\text { occlusion }\end{array}$ \\
\hline Gelfoam & Resorbable water-insoluble [38] & & $\begin{array}{l}\text { Ischemic and infectious complications } \\
\text { Dermatome paresis }\end{array}$ \\
\hline Oxycel/surgicel & Resorbable & No tissue reaction [39] & \\
\hline $\begin{array}{l}\text { Ethanol or } \\
\text { absolute alcohol }\end{array}$ & Resorbable & $\begin{array}{l}\text { Very effective Intravascular } \\
\text { use }\end{array}$ & $\begin{array}{l}\text { Untargeted } \\
\text { Neighboring tissues and skin necrosis }\end{array}$ \\
\hline Cyanoacrylate & $\begin{array}{l}\text { Fast and efficient non- } \\
\text { resorbable non-radiopaque } \\
\text { [40] }\end{array}$ & $\begin{array}{l}\text { Safe excellent control of the } \\
\text { glue penetration } \\
\text { Less painful }\end{array}$ & $\begin{array}{l}\text { Special skill and experience required } \\
\text { Ischemia or infarction of neighboring tissue }\end{array}$ \\
\hline $\begin{array}{l}\text { Detergent-type } \\
\text { sclerosants }\end{array}$ & Non-resorbable & $\begin{array}{l}\text { Not painful } \\
\text { Effective in lesions with little } \\
\text { flow } \\
\text { Less severe allergic and } \\
\text { inflammatory reactions [41] }\end{array}$ & $\begin{array}{l}\text { Anaphylactic shock, temporary trismus, pleural } \\
\text { effusion, pneumonia, and hemolytic reactions [42] }\end{array}$ \\
\hline $\begin{array}{l}\text { Coils and metallic } \\
\text { embolization }\end{array}$ & Non-resorbable & Permanent desired occlusion & $\begin{array}{l}\text { High cost } \\
\text { Less flexible }\end{array}$ \\
\hline Microcatheters & $\begin{array}{l}\text { Non-resorbable } \\
\text { Revolutionized } \\
\text { interventional radiology }\end{array}$ & $\begin{array}{l}\text { More flexible and small } \\
\text { Easier placement at distal } \\
\text { locations }\end{array}$ & Excellent fluoroscopy and digital imaging are requirec \\
\hline
\end{tabular}



Fig. 3 T2 weighted image showing venous malformation

hypertrophic obstructive cardiomyopathy in an infant with oral propranolol. Contrarily, Seigfried et al. warned for the side effects of propranolol which includes hypoglycemia, bradycardia, hypotension, bronchospasm, CHF, sleep disturbance and hypothermia and recommended the close monitoring of infants having propranolol therapy [18]. But in many case series reports, almost $100 \%$ efficacy has been reported in arresting these lesions, and vice versa, therapy failure has also been reported indicating use of alternate treatment modalities. Although many centers including the authors' have introduced this therapy as first line of treatment, trials are still going on to prove its efficacy and more conclusive data will be forthcoming [19].

\section{Steroids}

Use of steroids in VM started in 1963 after an accidental find when a case of a thrombocytopenic child on systemic steroids $(2-5 \mathrm{mg} / \mathrm{kg} /$ day) showed decrease in infantile hemangiomas [20]. In other large studies, when prednisolone was given in larger doses of $20 \mathrm{mg}$ daily, it evidenced an $84 \%$ response after 2 months of initiating the therapy [21]. But $35 \%$ rate of side effects was also documented with this relatively high response rate. It is suggested that a mixture of triamcinolone $40 \mathrm{mg} / \mathrm{ml}$ and betamethasone $6 \mathrm{mg} / \mathrm{ml}$ in $1: 1$ ratio is to be injected 


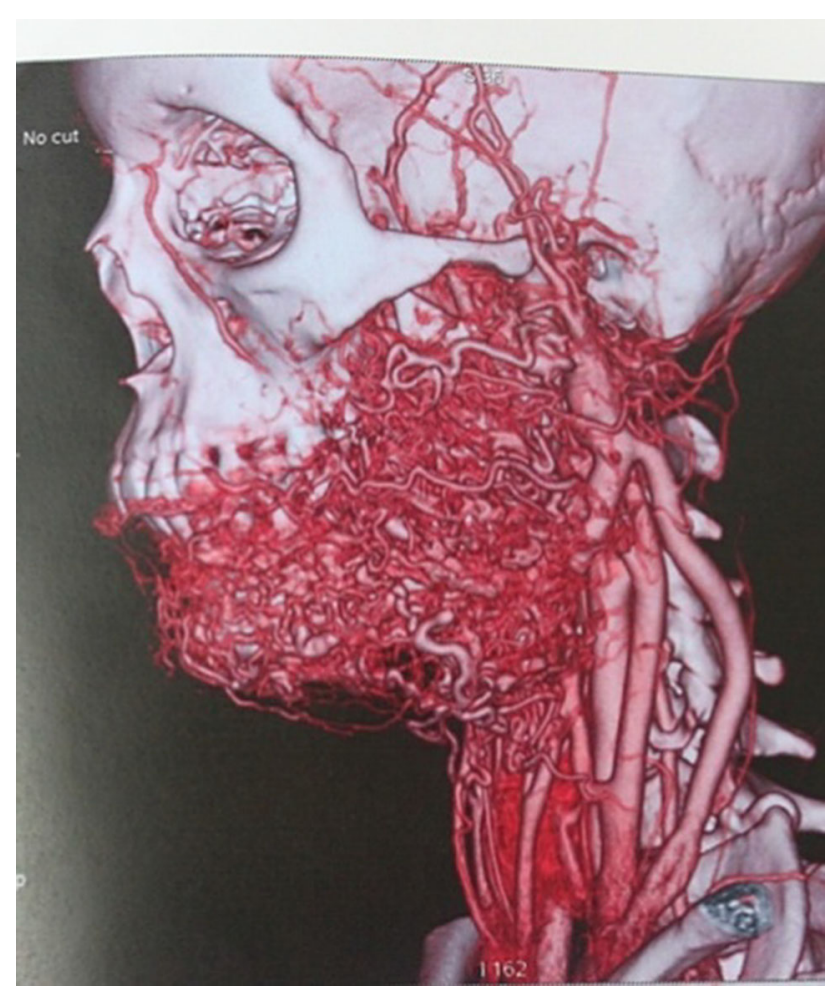

Fig. 4 64-slice spiral CT angiography (CTA)

1-2 $\mathrm{ml}$ intralesionally, response of which may be rapid, much more favorable and drastic in a matter of few days. Local complications, one may expect, are periocular ophthalmic artery embolization, fat atrophy, cutaneous hypopigmentation, full-thickness eyelid necrosis and calcification, but these are avoidable with skill adaptations and following proper technique with recommended dosage.

\section{Vincristine}

It is an alkaloid cancer chemotherapeutic agent which induces apoptosis by interference with mitotic spindle microtubule. It can thus be used as an alternative to steroids for infantile hemangioma because of steroid-sparing effects. Although it has been documented with side effects like hematologic toxicity, peripheral neuropathy, jaw pain and constipation, its favorable efficacious results overcome these known risks or side effects [22].

\section{Interferon Alpha}

It works as an anti-angiogenic agent with an advantage of steroid-saving effects. Although one case series documented regression of half or more lesions in $90 \%$ of cases treated by interferon alpha, this was associated with serious side effects of spastic diplegia and neutropenia [23]. Subsequently, this treatment modality was abandoned due to unacceptable high risk of neurotoxicity (10-30\%) with its use, despite its favorable efficacious results [24].

\section{Management of VM}

This is largely dependent on the fluid dynamics of the lesion. Preliminary imaging with US Doppler will differentiate a high flow from a low-flow lesion. In low-flow lesions with large vascular channels and spaces in the head and neck region, total excision is a surgical challenge and misadventure. The philosophy of management then hinges on decompressing the lesion or partial elimination. This
Fig. 5 Algorithm for management of vascular anomalies [11]

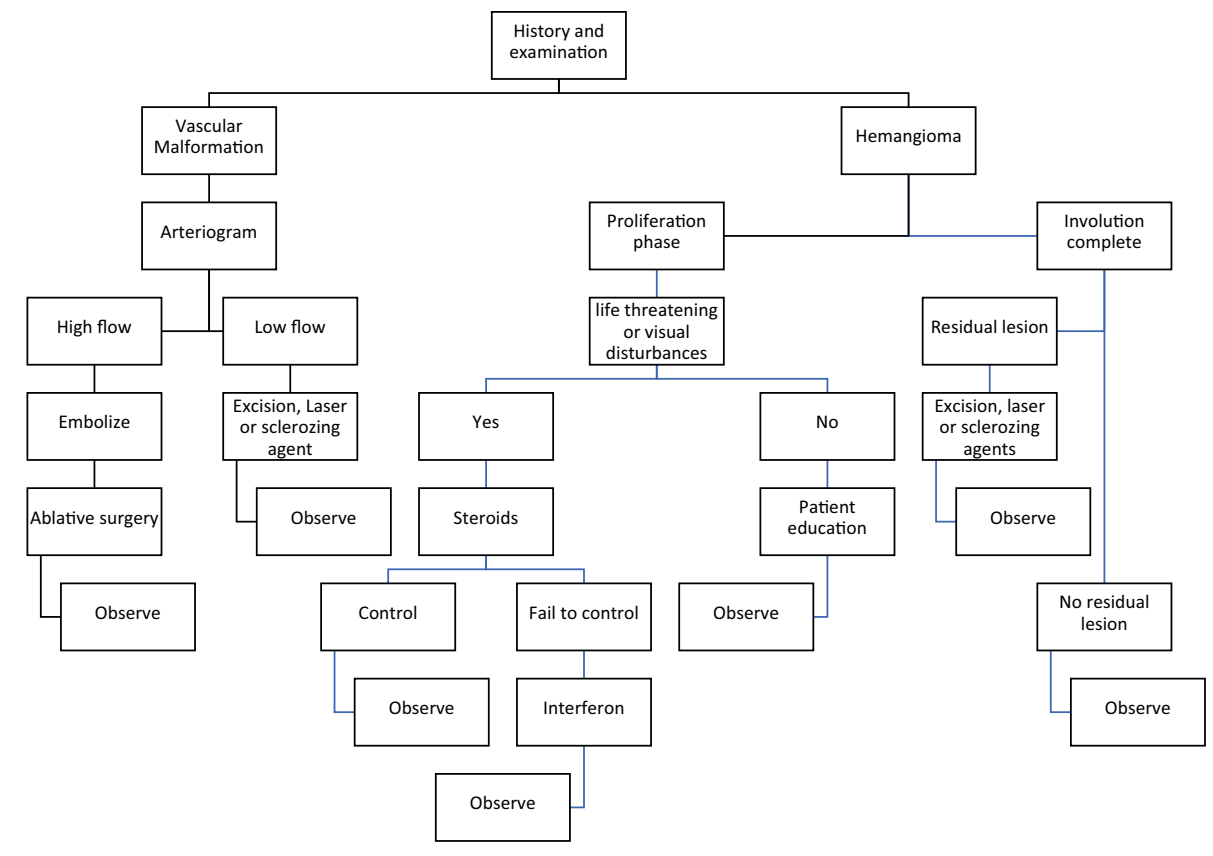


Fig. 6 Algorithm for management of congenital vascular anomalies [14]

\section{Therapeutic time scheme for CVA}

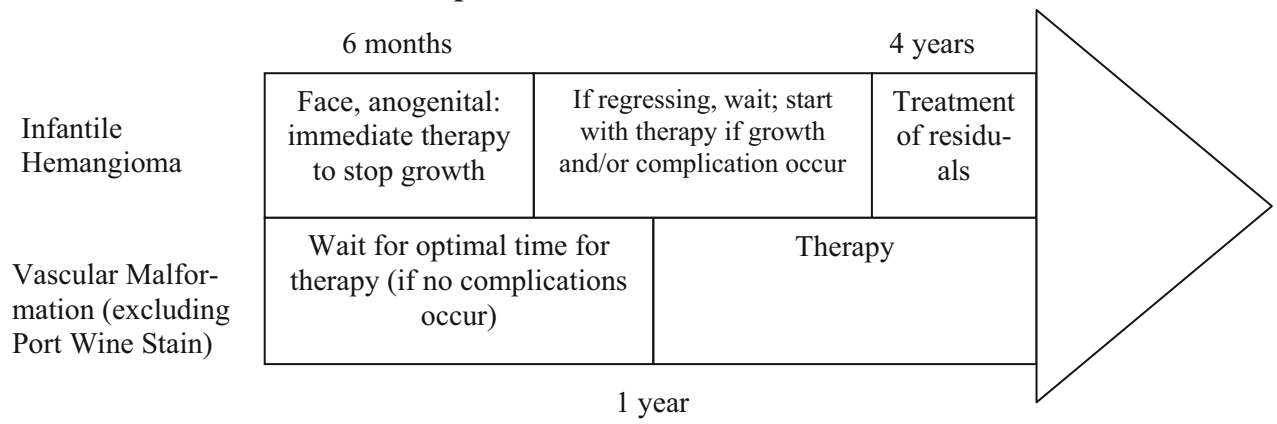

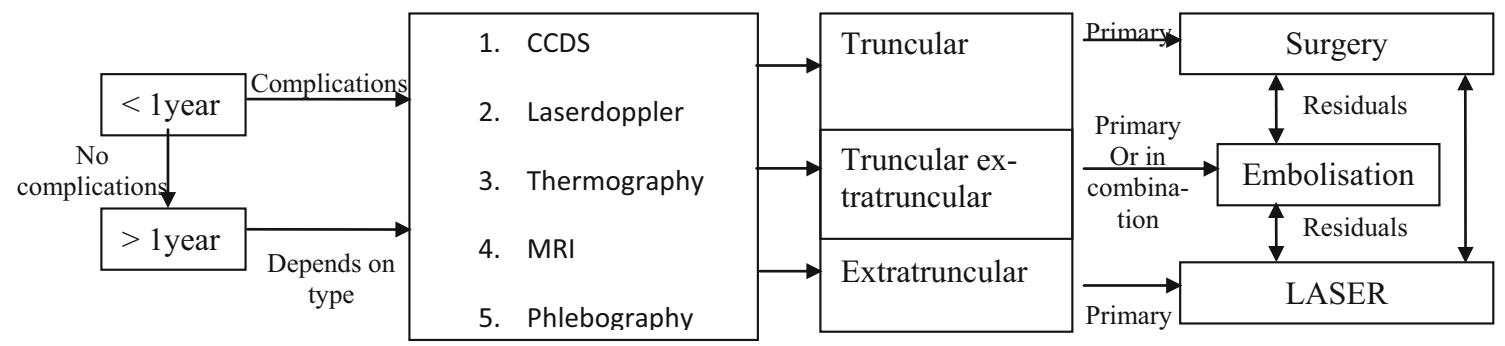

Fig. 7 Algorithm for management of vascular malformations [14]

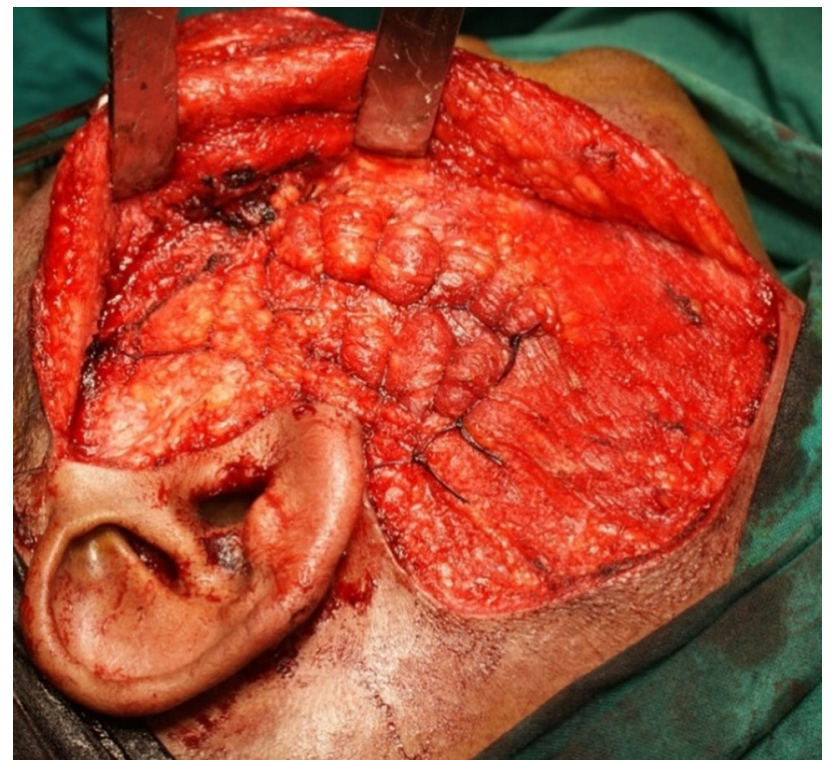

Fig. 8 Corset suturing

can be achieved with administration of intralesional medicaments which may be sclerosing in nature (Fig. 7).

\section{Intralesional sclerosants (Table 7)}

Sclerotherapy has become the current mainstream treatment for venous malformation. It can be used alone or combined with surgery and/or laser therapy. For large lesions, multiple treatments are necessary. Recurrence is seen; this may possibly happen with some sclerosing agents that

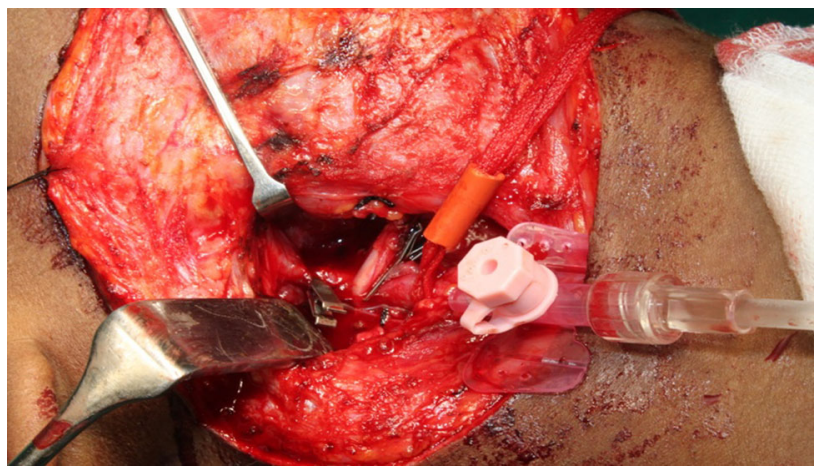

Fig. 9 Intraoperative ECA control

incompletely treat the VMs being injected. The sclerosants commonly used are 5\% sodium morrhuate, pingyangmycin (PYM), anhydrous ethanol and lauromacrogol.

The mechanism of action of these sclerosing agents is clearly understood and unique in destroying the blood vessel's endothelial cells, acceleration of protein coagulation in blood of lesions, formation of thrombosis, platelets adhesion promotion and causing vascular occlusion through thrombotic mechanisms.

\section{Laser Treatment}

One of the non-medicinal modalities of treatment employed in IH is laser. Several types of laser have been tried, including argon laser, Nd:YAG laser, carbon dioxide laser, fractional photothermolysis and pulsed dye laser (PDL). 


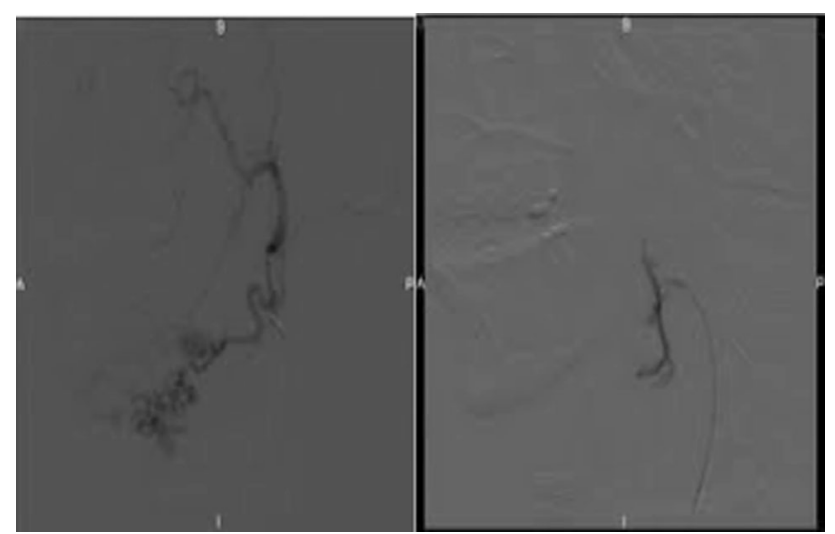

Fig. 10 Endovascular embolization

Nd:YAG laser and KTP laser are most frequently used laser systems in the treatment of vascular malformations. Mechanism of action lies behind the ability of hemoglobin to absorb laser energy and generating a high temperature and that causes coagulation and immediate shrinkage of lesion. As these laser systems have the tendency to penetrate only 1-3 mm and to form a scar on nerves or skin of superficial lesion, their interstitial use has been recommended [32].

\section{Surgical Management}

Surgery continues to be a viable alternative to all of the above modalities. Although it yields nearly instantaneous resolution of the lesion, it carries with it the risk of bleeding, despite the well-circumscribed nature of IH. Walker et al. demonstrated impressive clinical results following surgical removal of 12 visually significant hemangiomas, half of which had failed prior therapy; however, two of those cases also necessitated intraoperative blood transfusions due to hemorrhage [33]. Patients must be selected very carefully for excision accounting for the size, location and surgical risk to surrounding structures. Surgery is generally reserved for lesions that are refractory to less invasive treatments. Various techniques and technologies have aided in limiting and controlling intraoperative bleeding, rendering surgical excision a more favorable option in appropriate clinical scenarios.

The technique of intratumoral ligation was reported by Popescu in 1985 [34]. The aim of the treatment was to occlude by ligation the afferent and efferent vessels as well as the dilated vascular elements which make up the tumor mass. The technique required the use of large curved needles and strong suture material which would not cut out easily.

\section{Corset Suturing}

Similarly, the use of continuous vertical or horizontal mattress sutures helped compress the large venous compartments into smaller compartments which eventually replaces the vascular spaces with fibrous tissue. This technique was conveniently named Corset suturing by the
Fig. 11 Author's simplified algorithm

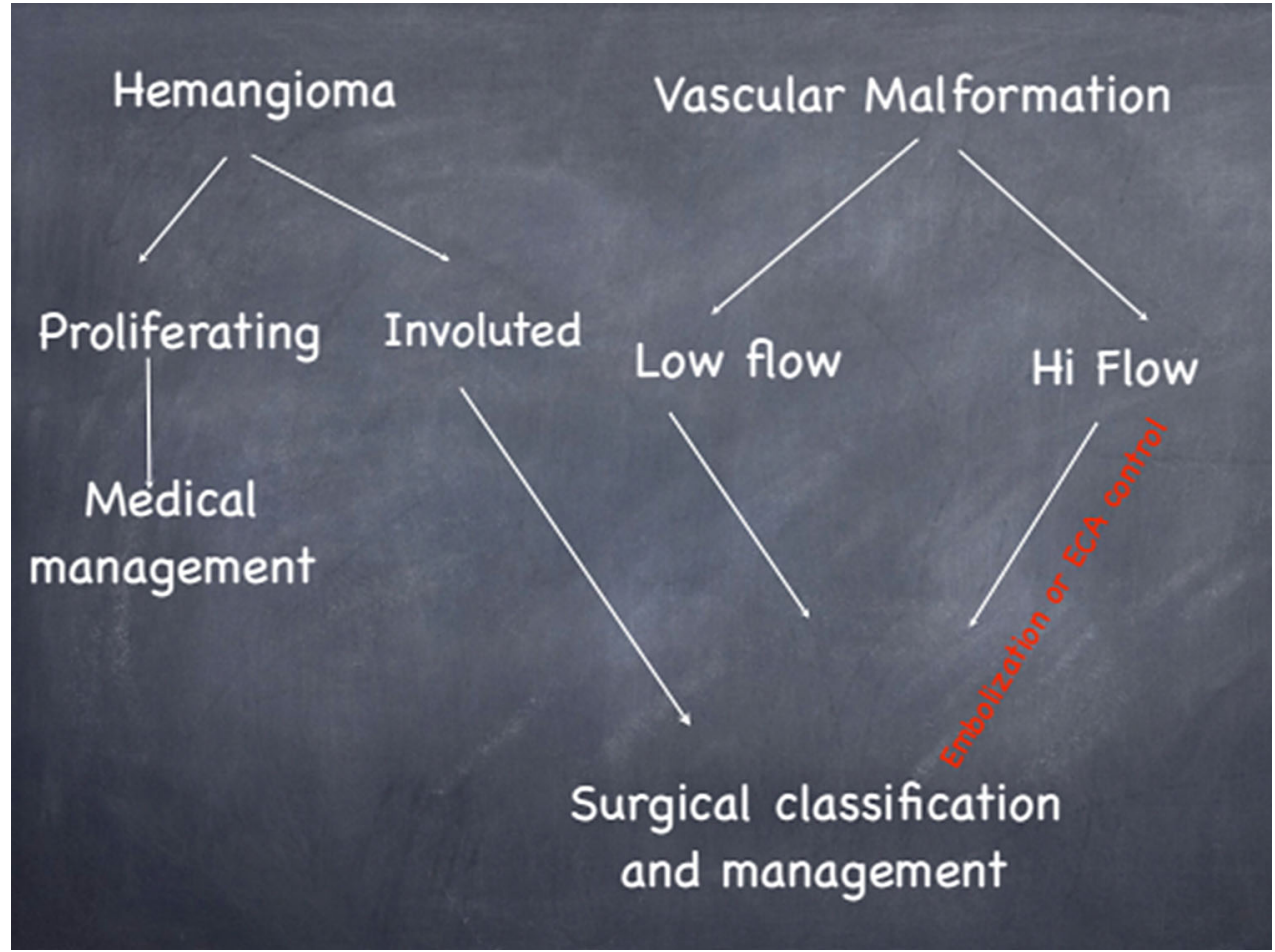


author. The use of long-standing PDS sutures helped in the fibrous transformation and helped reduce size of the lesion (Figs. 8, 9).

\section{Managing High-Flow Lesions}

High-flow lesions such as AM or AVM's had the risk of excessive hemorrhage intraoperatively and needed presurgical vascular control prior to its excision. Vascular control in high-flow lesions could be achieved by ECA control or endovascular embolization (Table 8).

The oldest form of surgical treatment for AVM's was proximal arterial ligation, which originated from Hunter's successful management of a popliteal aneurysm. This approach is rarely curative, however, and in fact runs a significant risk of compounding problems by putting a greater demand on collateral vessels. In this situation the collaterals not only sustain the original lesion but in the process of their subsequent enlargement act to increase its overall size. Judicious control rather than ligation was therefore the key.

\section{Vascular Control (Understanding Embolization)}

Embolization is defined as the "therapeutic introduction of various substances into the circulation to occlude vessels, either to arrest or prevent hemorrhaging; to devitalize a structure, tumor, or organ by occluding its blood supply; or to reduce blood flow to an arteriovenous malformation" [35].

Embolization has three therapeutic goals in the treatment of vascular malformations which are adjunctive goal, curative goal and palliative goal. Specific materials used for embolization are ethanol, cyanoacrylate, coils, polyvinyl alcohol, sodium tetradecyl sulfate, gelatin sponge and microspheres (Fig. 10).

Macrocoils and microcoils are of different sizes used for embolization. Platinum coils, type of microcoils, can be introduced into vascular system using microcatheters. These are highly radiopaque, thrombogenic and biocompatible. The potential disadvantages of this type of coil embolization are collateralization and proximal occlusion, making repeat embolization very difficult.

New interest has been inspired by the recent advances in terms of the course, its pathogenesis and successful treatment of infantile hemangiomas. One of the treatment modalities needs to be discussed here. As VEGF-A concentrations are high in infants with proliferative lesions, bevacizumab, an anti-VEGF antibody extracted from humans, has given remarkable results in early clinical trials in nosebleeds of patients suffering from hereditary hemorrhagic telangiectasia but currently clinical trials are still in process.
The management of vascular lesions starts from its very appearance and behavior. Identifying the type of lesion will determine its future management. There are several algorithms, as mentioned before, which help in the treatment protocol. The algorithm proposed by the author (Fig. 11) simplifies the decision making in the management of vascular anomalies.

In conclusion there are variables in managing individual vascular lesions and having a policy of "One size fits all" may be ill advised.

Acknowledgments I would like to acknowledge Dr. Jatinder Pal Singh Chawla, B M Jain Hospital, for his research in preparation of this article.

\section{References}

1. Nair SC, Spencer NJ, Nayak KP, Balasubramaniam K (2011) Surgical management of vascular lesions of the head and neck: a review of 115 cases. Int J Oral Maxillofac Surg 40(6):577-583

2. Adams AK (2002) Tarnished idol: William Thomas Green Morton and the introduction of surgical anesthesia. J R Soc Med 95(5):266-267

3. Mulliken JB, Young AE (1988) Vascular birthmarks: hemangiomas and malformations. Saunders, Philadelphia

4. Virchow R (1863) Angioma in die krankhaften Geschwtilste, vol 3. Hirshwald, Berlin, pp 306-425

5. Dasgupta R, Fishman SJ (2014) ISSVA classification. J Semin Pediatr Surg 23(4):158-161

6. Orlow SJ, Isakoff MS, Blei F (1997) Increased risk of symptomatic hemangiomas of the airway in association with cutaneous hemangiomas in a "beard" distribution. J Pediatr 131(4):643-646

7. Callahan AB, Yoon MK (2012) Infantile hemangiomas: a review. Saudi J Ophthalmol 26(3):283-291

8. Schwartz SR, Blei F, Ceisler E (2006) Risk factors for amblyopia in children with capillary hemangiomas of the eyelid and orbit. J AAPOS 10:262-268

9. Syed NM (2016) Vascular lesions of head and neck: a literature review. Indian J Dent Sci 8:176-182

10. Zheng JW, Mai HM, Zhang L et al (2013) Guidelines for the treatment of head and neck venous malformations. Int J Clin Exp Med 6(5):377-389

11. Fonseca RJ, Turvey RD, Timothy A, Marciani RD, Turvey TA (2000) Surgical pathology, vol 5. Textbook of oral and maxillofacial surgery. Saunders, Philadelphia

12. Lowe LH, Marchant TC, Rivard DC, Scherbel AJ (2012) Vascular malformations: classification and terminology the radiologist needs to know. Semin Roentgenol 47:263-272

13. Sivapathasundharam (2009) Shafer's textbook of oral pathology. Elsevier, India

14. Mattassi R, Loose DA, Vaghi M (2015) Hemangiomas and vascular malformations: an atlas of diagnosis and treatment. Springer, Berlin

15. Enjolras O (1997) Classification and management of the various superficial vascular anomalies: hemangioma and vascular malformation. J Dermatol 24:701-710

16. Sas TN, Boutsiadis N (2010) Facial hemangiomas diagnosis. Curr Health Sci J 36(3):166-170

17. Léauté-Labrèze $\mathrm{C}$, Dumas de la Roque E, Hubiche T, Boralevi F, Thambo JB, Taïeb A (2008) Propranolol for severe hemangiomas of infancy. N Engl J Med 358(24):2649-2651 
18. Siegfried EC, Keenan WJ, Al-Jureidini S (2008) More on propranolol for hemangiomas of infancy. N Engl J Med 359(26):2846

19. Meena M (2011) Re: "propranolol for the treatment of orbital infantile hemangiomas". Ophthalmic Plast Reconstr Surg 27(5):392

20. Katz HP (1965) Thrombocytopenia associated with hemangiomata: critical analysis of steroid therapy. In: XI international congress of pediatrics, Tokyo, p 336-367

21. Bennett ML, Fleischer AB Jr, Chamlin SL, Frieden IJ (2001) Oral corticosteroid use is effective for cutaneous hemangiomas: an evidence-based evaluation. Arch Dermatol 137(9):1208-1213

22. Enjolras O, Brevière GM, Roger G, Tovi M, Pellegrino B, Varotti E (2004) Vincristine treatment for function- and life-threatening infantile hemangioma. Arch Pediatr 11(2):99-107

23. Ezekowitz RA, Mulliken JB, Folkman J (1992) Interferon alfa-2a therapy for life-threatening hemangiomas of infancy. N Engl $\mathrm{J}$ Med 326(22):1456-1463

24. Frieden IJ, Haggstrom AN, Drolet BA, Mancini AJ, Friedlander SF, Boon L (2005) Infantile hemangiomas: current knowledge, future directions. In: Proceedings of a research workshop on infantile hemangiomas, 7-9 April 2005, Bethesda. Pediatr Dermatol, vol 22(5), pp 383-406

25. Mabeta P, Ionescu GO, Muir T, et al. (2004) Bleomycin levels in patients undergoing intralesional Bleomycin treatment for lymphatic malformation. Paper presented at fifteenth congress of the international society for the study of vascular anomalies. Wellington

26. Sanlialp I, Karnak I, Tanyel FC et al (2003) Sclerotherapy for lymphangioma in children. Int $\mathrm{J}$ Pediatr Otorhinolaryngol 67:795-800

27. Yakes WF, Haas DK, Parker SH et al (1989) Symptomatic vascular malformations: ethanol embolotherapy. Radiology 170(3 Pt 2):1059-1066

28. Sung MW, Lee DW, Kim DY et al (2001) Sclerotherapy with picibanil (OK-432) for congenital lymphatic malformation in the head and neck. Laryngoscope 111:1430-1433

29. Shin BS, Do YS, Lee BB et al (2005) Multistage ethanol sclerotherapy of soft-tissue arteriovenous malformations: effect on pulmonary arterial pressure. Radiology 235:1072-1077

30. Rebuffini E, Zuccarino L, Grecchi E, Carinci F, Merulla VE (2012) Picibanil (OK-432) in the treatment of head and neck lymphangiomas in children. Dent Res J 9(Suppl 2):S192-S196
31. Arnold R, Chaudry G (2011) Diagnostic imaging of vascular anomalies. Clin Plast Surg 38(1):21-29

32. Kishimoto Y, Hirano S, Kato N, Suehiro A, Kanemaru S, Ito J (2008) Endoscopic KTP laser photocoagulation therapy for pharyngolaryngeal venous malformations in adults. Ann Otol Rhinol Laryngol 117:881-885

33. Hohenleutner S, Badur-Ganter E, Landthaler M, Hohenleutner U (2001) Long-term results in the treatment of childhood hemangioma with the flashlamp-pumped pulsed dye laser: an evaluation of 617 cases. Lasers Surg Med 28(3):273-277

34. Choe DH, Moon HH, Gyeong HK et al (1997) An experimental study of embolic effect according to infusion rate and concentration of suspension in transarterial particulate embolization. Invest Radiol 32:260-267

35. Stedman T (2000) Stedman's medical dictionary, 27th edn. Lippincott Williams \& Wilkins, Philadelphia

36. Link DP, Strandberg JD, Virmani R et al (1996) Histopathologic appearance of arterial occlusions with hydrogel and polyvinyl alcohol embolic material in domestic swine. J Vasc Interv Radiol 7:897-905

37. Laurent A, Beaujeux R, Wassef M et al (1996) Trisacryl gelatin microspheres for therapeutic embolization, I: development and in vitro evaluation. Am J Neuroradiol 17:533-540

38. Berenstein A, Russel E (1981) Gelatin sponge in therapeutic neuroradiology: a subject review. Radiology 141:105-112

39. Leung JWT, Gotway MB, Sickles EA (2005) Preoperative embolization of vascular phyllodes tumor of the breast. AJR Am J Roentgenol 184(3 Suppl):S115-S117

40. White RI, Standberg JV, Gross GS, Barth KH (1977) Therapeutic embolization with long-term occlusing agents and their effects on embolized tissues. Radiology 125:677-687

41. Yamaki T, Nozaki M, Sasaki K (2000) Color duplex-guided sclerotherapy for the treatment of venous malformations. Dermatol Surg 26:323-328

42. Goldman MP (1991) A comparison of sclerosing agents. Clinical and histologic effects of intravascular sodium Morrhulate, Ethanolamine Oleate, hypertonic saline $(11.7 \%)$, and Sclerodex in the dorsal rabbit ear vein. J Dermatol Surg Oncol 17:354-362 